\title{
Ensuring access to water for food production by emerging farmers in South Africa: What are the missing ingredients?
}

\author{
C Chikozho', R Managa² and T Dabata ${ }^{2}$ \\ 'African Population and Health Research Centre, Nairobi, Kenya \\ ${ }^{2}$ Africa Institute of South Africa-HSRC, Pretoria, South Africa
}

One of the key components essential to the productivity of small-scale farmers who secured farms through the land redistribution programme in South Africa is access to reliable sources of water for irrigation. In this study, we deployed a stakeholder-oriented qualitative research methodology to understand the extent to which land reform farming schemes in Bela-Bela and Greater Sekhukhune have been able to access water and use it to enhance their agricultural production. We were keen to identify and articulate the water-related challenges and missing ingredients for successful agricultural production on the new farming schemes. The study found that access to water for irrigated agriculture is not guaranteed for most of the emerging farmers and they do not have the finance needed to invest in sustainable water supply systems for irrigation. As a result, the majority of the farmers in our study sample have not been able to realize any meaningful agricultural production, with their farming schemes being either underutilized or not functioning at all. Other key challenges include lack of finance, high costs of electricity, and lack of farming knowledge among the emerging farmers. The paper concludes that there is need for key actors in the development sector to provide more substantive post-land transfer support and ensure better access to water for the emerging farmers. This will enhance the farmers' chances of realizing more meaningful agricultural production while improving their livelihoods.

\section{INTRODUCTION}

Since the mid-1990s, the Government of South Africa has been grappling with the design and implementation of land redistribution reforms that are intended to ensure equitable sharing of the nation's means of agricultural production through transfer of commercial farms from the predominantly white owners to black farmers (emerging farmers). However, the success of land redistribution remains a highly contested issue in the country's development discourses, particularly with regards to the extent to which the programme has achieved its main goals and expected outcomes. In this regard, several studies have been done which mainly focus on the extent to which the government has managed to facilitate actual transfers of land (in volumetric terms) from white commercial farmers to the emerging farmers. This has resulted in many publications that articulate the failures of the willing-buyer-willing-seller approach and how some white commercial farmers have used their resources and agency to side-step the reforms and neutralize reform efforts that once promised to catalyse inclusive development in the post-apartheid era (see Cousins, 2005; Hall, 2007, 2009, 2010; Kepe, 2009; Kleinbooi, 2010; Atuahene, 2011; MéndezBarrientos, et al. 2018).

There are also other related studies that have sought to unravel the intricacies of the new water governance regime emerging from the water reform process and how it affects access to water. These studies tend to place special attention on the appropriateness of the new water legislation promulgated in 1998 and how it may enable catchment management agencies to contribute to better water management under the new dispensation (see Anderson et al., 2008; Van Koppen, 2008; Movik, 2009, 2014; Swatuk, 2010; Msibi et al., 2011; Schreiner and Hassan, 2011; Woodhouse, 2012; Thiam et al., 2015). There are indications that even after almost two decades of water reform implementation, access to water remains highly skewed along racial lines, and the envisaged massive socio-economic transformation of rural communities and landscapes has remained a pipe-dream (Kemerink et al., 2011).

Closer analysis of the published literature shows that there have been very few studies done in South Africa that acknowledge the link between land and water even though this connection may seem self-evident. For instance Merrey et al. (2009) demonstrated how monopoly and extreme inequity in ownership and access to water in the Olifants Catchment created artificial water scarcity for emerging farmers; Liebrand et al. (2012) argue that in spite of its explicit focus on equity, the National Water Act (Act 36 of 1998; RSA, 1998) did little to bring about a more just allocation and use of water and, as a result, access to both land and water in South Africa continues to be concentrated in the hands of a privileged few, and is highly skewed along racial lines. It is our contention that such studies enable analysts to get a better grasp of how emerging farmers may gain access and use water in practice to make their farms more productive. Therefore, while most of the earlier studies generated a better understanding of the 'what, why and how' of land and water reforms, limited attention was paid to the interface between land acquisition and water access and

\section{CORRESPONDENCE}

C Chikozho

\section{EMAIL}

c.chikozho@gmail.com

\section{DATES}

Received: 22 January 2019 Accepted: 31 March 2020

\section{KEYWORDS}

emerging-farmers irrigation

land reform

livelihoods

water-access

\section{COPYRIGHT}

() The Author(s)

Published under a Creative Commons Attribution 4.0

International Licence (CC BY 4.0) 
use for the emerging farmers. The main aim of this study was to generate empirical data that demonstrates the extent to which access to water may or may not be assured for the emerging farmers as well as the barriers to water use that they face. We assumed that addressing the challenges that these farmers face in accessing and using water partly determines whether or not they smoothly transition from subsistence to commercial farming.

Our study is unique in that it focused on gaining an in-depth understanding of on-farm processes for accessing and using water to enable more meaningful agricultural production by emerging farmers who have very diverse needs, and how the barriers they face in this context may be addressed. In this paper, we argue that there is need for key actors in the sector to pause and reflect on what else needs to be done to enable the reforms to positively transform the rural socio-economic landscape in the country. We focus more on the outcomes (the 'so what?') of the reform process, thereby departing significantly from the post land transfer descriptions of the reform process that dominated earlier analyses by other scholars. In doing this, we begin to identify the water- and non-water-related missing ingredients for successful agricultural production among the emerging farmers.

The foregoing is particularly crucial in a national context where, after two decades of implementation of the land and water reforms, the public mood is not necessarily one of celebrating successful transformation of livelihoods through planned redress of historical inequities in the ownership of the means of production. Instead, national discourses on these reforms are progressively shifting towards possibilities of quickening the pace of land expropriation without compensation, with the hope that this will catalyse more significant transformation on the ground. In essence, this paper brings sharper focus to bear on the challenges evident at the intersection of the land reform terrain and the commercial farming water supply regime in South Africa. It is intended to inform the development of more effective water policy and meaningful post-land transfer support systems in the country, and thus transform the livelihoods of beneficiaries of the land redistribution programme.

\section{BACKGROUND}

In hydrological terms, South Africa is categorized as waterscarce, with more than $60 \%$ of the country receiving less than $500 \mathrm{~mm}$ of rainfall per annum, while $21 \%$ receives less than 200 $\mathrm{mm}$, and only $7 \%$ of the total area of the country receives more than $800 \mathrm{~mm}$ per annum (Schulze, 1997). It is ranked as the $30^{\text {th }}$ driest country in the world in terms of available water per capita (Schreiner et al., 2010). Irrigated agriculture accounts for almost $30 \%$ of all commercial farm crop production and is the single largest user of water in the country (Fanadzo et al., 2010). Given the scenario of water scarcity in the country, access to reliable water supplies for the emerging farmers' irrigated agricultural production activities becomes vital. At the same time, in intellectual and public policy discourses surrounding the land reform process, the importance of water as a productive force that enables historical redress in irrigated agriculture assumes widespread recognition (Goldin, 2010).

The discrimination and inequity characterizing access to land in the country inevitably extended to the distribution of water resources (Movik, 2014). The 1956 Water Act, for instance, was founded on the doctrine of riparianism, which implied that only those individuals owning land adjacent to rivers and other sources of water were entitled to 'reasonable use' of water. Most of the riparian landowners were white farmers, who enjoyed generous government subsidies, and this needed to be addressed urgently soon after apartheid (Bate and Tren, 2002). Thus, for emerging farmers who obtain land through the land redistribution programme, water becomes one of the most significant resource constraints in a situation where many parts of the country experience huge variations in temporal and spatial distribution of rainfall (WWF, 2014).

The main thrust of the South African National Water Act (1998) was to redress water allocation inequities in a way that enables all racial groups to access and use water for productive purposes (Goldin, 2010). One of the instruments used to try to redress these inequities was the redistribution of formal water use rights, primarily through the process of compulsory licensing (Anderson et al., 2008; Movik, 2014). Essentially this required all current and future water users for productive purposes to apply for a water license, particularly in river basins and catchments that are already over-allocated or facing water scarcity. However, the legislation did not deal specifically with exactly how the water rights should be re-allocated in practice (Perret, 2002). At the same time, both water and land reform were initiated and implemented as two separate processes, and thus not necessarily guaranteeing access to water for the emerging farmers.

There are several studies that have concluded that the South African agricultural economy has little room for emerging farmers because there is no strong support system for the previously disadvantaged farmers, and this includes lack of support for accessing water (Moloi, 2010; Ayinke, 2011; Chikazunga and Paradza, 2012). This suggests that it is almost impossible for the emerging farmers to take full advantage of the various opportunities that the South African Government has put in place for small-scale irrigated agriculture. Schreiner and Hassan (2011) argue that neither government nor civil society has been very effective in tapping the potential of water storage and infrastructure development on a large enough scale to mitigate seasonal and annual variability and unpredictability of rainfall, and thus improve year-round productivity of agriculture-based livelihood strategies, such as cropping, horticulture, livestock, tree growing, brick making, crafts, and small-scale enterprises. Instead, the then Department of Water Affairs mainly focused on the regulation of existing and new large-scale water uses, among others, through the new water governance regime which is based on water use licensing (ibid).

It is also important to note that even though the National Water Act of 1998 vaguely mentions the need to achieve optimal allocation of water resources and encourage beneficial use of water for the public good, it remained unclear how these concepts should be interpreted and practically implemented on the ground (Movik, 2014). This has left the emerging farmers uncertain about how to gain access to water on their newly acquired farms. In addition, the recognition of existing 'lawful uses' in the water legislation ensured that the status quo would be maintained and agricultural production would not be disrupted, but in the process, marginalizing the larger history of inequitable land and water acquisition (ibid). The failure to approach reform in a more holistic manner through integration of land and water reforms, combined with the cautious 'balanced' approach of seeking re-allocation without threatening large-scale users, are some of the major factors that retarded progress (Merrey, 2008).

Throughout the world, access to water and irrigation facilities gives farmers the assurance they need to grow crops and rear livestock without losing them to drought, and thus has been rightly identified as the driving force in the agricultural development strategy proposed by the South African National Planning Commission (2012). However, it is also increasingly apparent that the South African Government's goal of redistributing land and water whilst maintaining the same 
levels of commercial agricultural production to ensure food security has not produced the expected results in terms of the original equity objectives (Ntsebeza, 2007; Umhlaba, 2010; Kepe and Tassaro, 2014). Thus, in spite of pertinent legal and policy statements about the re-allocation of water from the 'haves' to the 'have-nots', water reforms seem to have had limited impact in terms of racial transformation of resource ownership in the sector (Schreiner and Hassan, 2011). In this study, we revisited the issue of access and use of water for the emerging farmers in the Bela-Bela and Greater Sekhukhune municipal areas and their surroundings to generate more knowledge and articulate the challenges that the farmers face.

\section{Study sites}

\section{Limpopo Province}

The Limpopo Province is approximately $123910 \mathrm{~km}^{2}$ in size (or 12.5 million ha). Its population has grown to about 5.4 million people (Stats SA, 2012). Roughly $84 \%$ of the province may be categorized as rural. For many years, the province itself has been considered as the second-poorest in the country (after Eastern Cape Province), with $89 \%$ of the population living in rural areas (Lahiff et al., 2008). It is estimated that $63 \%$ of the province's total land area (roughly 7.5 million ha) is owned by white commercial farmers (Stats SA, 1998). The province is constituted by 5 districts: Capricorn, Mopani, Sekhukhune, Vhembe, and Waterberg. Our study was carried out in Bela-Bela Municipal area in the Waterberg District and Groblersdal Municipal area in Greater Sekhukhune District (Fig. 1).

Three main land-use categories are identifiable in the province. These are: land under commercial agricultural use; rural areas that are home to millions of smallholder farmers practising rainfed agriculture in the former homeland areas; and land under conservation which is home to wildlife species (Cardno Agrisystems Limited, 2008). Agriculture contributes approximately $2 \%$ of the province's economy and $7 \%$ of total national agriculture contribution to GDP (Provincial Review, 2016).

\section{Greater Sekhukhune}

Greater Sekhukhune District is South Africa's second-largest irrigation settlement. It is a cross-border district municipality straddling the boundary between the southern part of the Limpopo Province and the north-western portion of the Mpumalanga Province but wholly within the Olifants River Basin (Local Government Handbook, 2012). It consists of 5 local municipalities: Fetakgomo, Greater Marble Hall, Greater Tubatse, Makhuduthamaga and Greater Groblersdal. The spatial area of the district is approximately 1326 437ha (Greater Sekhukhune District Municipality, 2008). The district is close to urban centres such as Pretoria, Polokwane and Mbombela which provide a ready market for agricultural products. Compared to other areas in the province, the greater Sekhukhune District ranks the highest in terms of poverty, with about $70 \%$ of the population in both 2007 and 2010 living below the poverty line. It is also characterised by poor infrastructure and lack of safe water supplies. Some $33 \%$ of the population still depend on natural water supply and $7 \%$ have no formal means of sanitation (Drimie et al., 2009; Magombeyi, 2013).

Commercial agriculture provides the bulk of employment opportunities in the district, but more than half of the population $(64.8 \%)$ is unemployed, particularly the youth (Stats SA, 2011). Although the district is viewed as having a high agricultural potential, $70 \%$ of the farmers, mostly black, are 'subsistence farmers' (Greater Sekhukhune District Municipality, 2008). Of these, $30.4 \%$ have access to land outside of their small homestead plots (Stats SA, 2011). The existence of very limited opportunities for employment has caused many people to migrate from the area to urban centres in Mpumalanga, Limpopo and Gauteng Provinces. Sekhukhune District is in a semi-arid hydrological region that receives about $450-500 \mathrm{~mm}$ of rainfall annually, with most of it in summer (Nowata, 2014). Low precipitation levels have made water scarcity an ongoing challenge in Sekhukhune District. Not only is the area drought-prone, but most of the available water has already been allocated to economic sectors such as tourism, commercial agriculture, industrial and domestic uses. Among all these sectors, it is generally agreed that

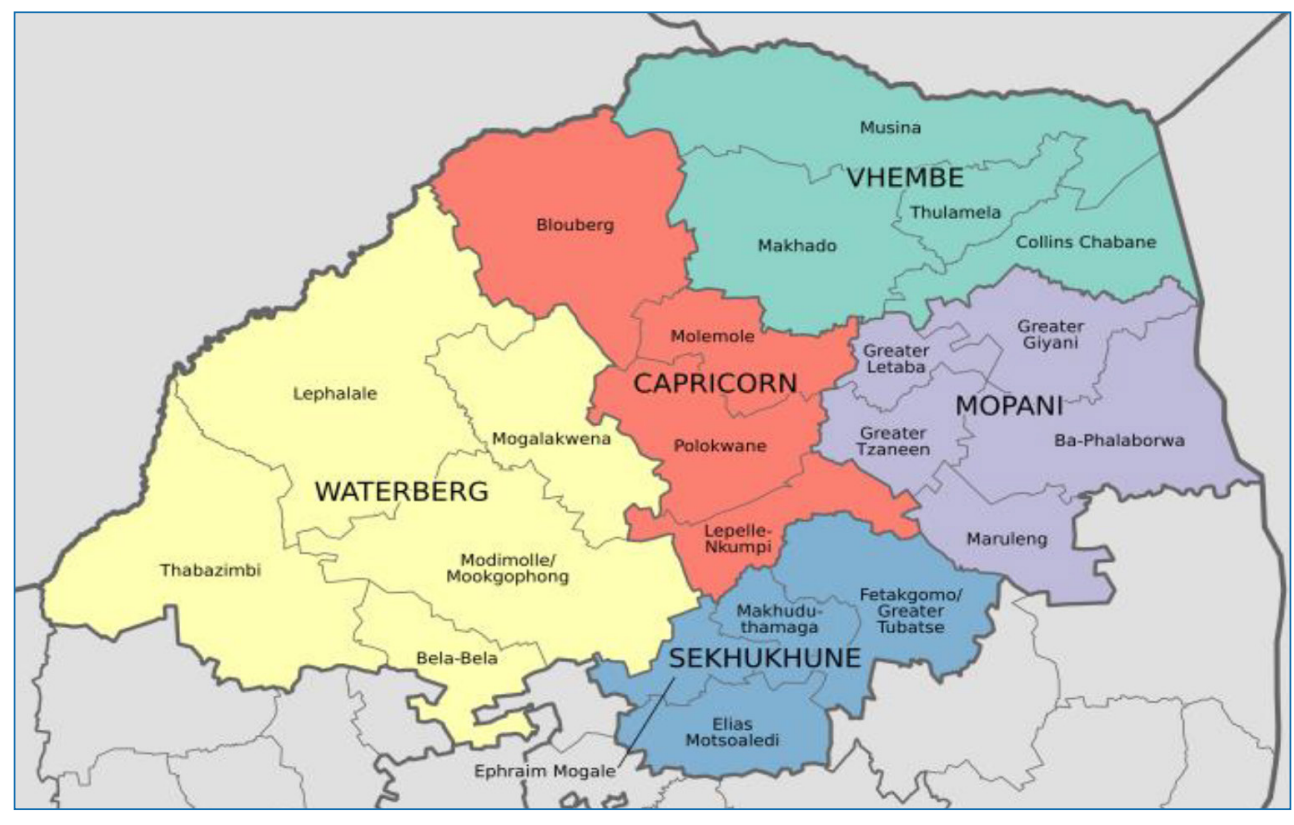

Figure 1. Location of the study sites (adapted from Greater Sekhukhune District Municipality, 2008) 
the well-established commercial farming sector accounts for the bulk of water abstractions (Magombeyi, 2013). By contrast, emerging small-scale irrigation farmers have insufficient water and some interventions are required to improve water access for this sector which is likely to grow further as more users enter the sector through land reform (Farolfi and Perret, 2002).

\section{Bela-Bela}

Bela-Bela Municipality is situated in the south-western region of the Waterberg District in the Limpopo Province. It shares borders with Gauteng, Mpumalanga and North West Provinces as well as with Modimolle Municipality to the north and Thabazimbi to the west (Heetderks, 2015). The approximate total area of the municipality is $4000 \mathrm{~km}^{2}$. The most important economic clusters within the municipality include tourism, agriculture, and mining. Agriculture contributes about 32\% of the District's economy while mining contributes $48 \%$ (UrbanEcon., 2007).

Being approximately $100 \mathrm{~km}$ from Pretoria, $200 \mathrm{~km}$ from Polokwane, and $170 \mathrm{~km}$ from Johannesburg, Bela-Bela is directly linked to these major cities through the National (N1) Route. This spatial linkage with the major cities created the opportunity for Bela-Bela to develop into a major holiday destination and a location for major private investments, especially in the tourism industry (Bela-Bela Municipality, 2013). Large-scale commercial farmers, who are predominantly white, are still present and quite visible in the area. However, through government-funded land reform projects, there is a rising number of black commercial farmers (ibid). The area has fertile soils and a relatively warm winter, which presents opportunities for the cultivation of high value crops such as vegetables, flowers, and herbs throughout the year (Heetderks, 2015). The area also has significant underground water reserves that enable supplementary irrigation when the rains are not consistent.

\section{RESEARCH METHODS}

This paper is based on results from an exploratory applied qualitative study which used small-scale irrigated farms emerging from the land redistribution process in the Limpopo Province as case studies that demonstrate the efficacy of the reform processes. Getting a good understanding of the various settings and processes guiding access to water and land reform required us to spend time on the selected farming schemes and interact with the farmers and other stakeholders involved for extended periods of time. Empirical data collection and direct observations were done on each of the farms in our sample from 2015 to 2018. Through the assistance of district-level Department of Agriculture officials, we obtained the land reform database for Limpopo Province. They also helped us in accessing the study sites. An examination of the database provided us with a general overview of the land redistribution terrain in the study sites.

Bela-Bela municipal area was the main study site where we concentrated most of our resources for the research while Groblersdal in Greater Sekhukhune District was a secondary study site. An examination of the land reform database for Limpopo and consultations with agricultural extension officers indicated that there was a total of about 50 smallscale new commercial farming schemes arising from the land redistribution programme in the Bela-Bela municipal area and 34 schemes in Groblersdal. We intended to cover all of the farms identified but we ended up covering only 40 of them in BelaBela and 23 in Groblersdal because we found some of them unoccupied and could not locate the owners. Nonetheless, the total number of schemes covered was more than sufficiently representative at over $60 \%$ coverage in both sites, particularly if one considers issues of parsimony. In other words, even though the deserted farms directly reduced the size of our sample, we felt that the findings from the smaller sample were still sufficient enough to give a relatively good picture of the emerging farmer water access challenges and opportunities. Since the study was mainly qualitative, we adjudged that the sample we reached was large enough for us to assume that, due to parsimony, it was highly unlikely that our findings would change significantly even if we had managed to reach a larger number of respondents.

Using a semi-structured interview guide, we captured the views of the farmers and other key stakeholders as they explained what they thought actually happened or should have happened to enable more effective implementation of the reforms, enhance access to water for the emerging farmers, and by extension, improve agricultural production through small-scale irrigation. We interviewed about 15 key informants in Bela-Bela and 5 in Groblersdal. These were mainly composed of agricultural extension officers; development agencies active in the land reform sector; local government officials responsible for water service provision, agriculture, and rural development. These stakeholders were mainly targeted because of their direct involvement in and knowledge of the reform processes in their geographical areas of jurisdiction.

In essence, we sought to find out how the emerging farmers and other key actors relate to the biophysical and institutional aspects of the local water access regime. Key questions on the interview guide enabled us to prompt the farmers to give us a detailed narration on how they acquired the farm; the steps they followed to enable access to water; the specific challenges they faced in this process and how they managed or failed to overcome them; how the available water is actually used; and ultimately, options for improving overall access to water for their irrigation purposes. Most of the interviews were conducted in native languages easily understood by the farmers and were subsequently translated into English.

Through detailed deliberations with key stakeholders in the sector, we developed simple criteria for a typically successful emerging farmer who has reliable access to water as being mainly constituted by the following:

(i) The farm is occupied and running as a single commercial agricultural entity.

(ii) The farmer has the required infrastructure and is using irrigation for commercial crop and/ livestock production rather than just for subsistence purposes, with access to a reliable source of water assured.

(iii) The household is actually benefiting from stocks and flows of food and income arising from water use.

(iv) The farmer exhibits confidence in the water supply and irrigation system and has clear plans in place to continue sustaining the system.

Data from the key informant interviews was analysed and synthesized according to pre-determined sub-themes that enabled identification of major trends and patterns of water access and use. The main sub-themes considered were access to and use of water; ownership of water licences; availability of irrigation infrastructure; and other constraints beyond access to water. Data presentation is mainly in the form of simple measures of central tendency that are supported by detailed qualitative narratives.

\section{Ethical considerations}

Ethical approval for the study was obtained from the Human Sciences Research Council Ethics Committee in Pretoria, South Africa, before data collection was done. This included addressing 
issues about the protection of respondents from any harm that might arise from the study, maintaining confidentiality of information gathered, and ensuring voluntary consent before enrolling participants in the study.

\section{STUDY FINDINGS}

In both Bela-Bela and Groblersdal, the farms in the study sample were very diverse in terms of their size, farming activities, production challenges, crop yields, and access to water and other support systems.

\section{Access to water}

Table 1 presents findings regarding access to water for the farmers in our study sample. Out of a total of 63 farms under observation during the study, $40 \%$ had reliable access to water, while those with challenges in having access to water accounted for $60 \%$ of the sample. When breaking down the analysis by geographical study site, there was no significant difference between the two study sites, particularly in terms of the farmers accessing a reliable source of water, which was less than half of the total number of farms sampled in each area

Data in Table 1 show that the majority $(60 \%)$ of the emerging farmers in our study sample face challenges in accessing water. A related observation we made is that not all the farms

Table 1. Access to water on the selected farms in Bela-Bela and Greater Sekhukhune; $n=63$

\begin{tabular}{lcccc}
\hline Assessment variables & \multicolumn{1}{c}{ Bela-Bela } & Groblersdal & Total & $\%$ \\
\hline $\begin{array}{l}\text { Farm has reliable access } \\
\text { to water }\end{array}$ & 15 & 10 & 25 & 40 \\
$\begin{array}{l}\text { Farm has challenges in } \\
\text { accessing water }\end{array}$ & 25 & 13 & 38 & 60 \\
\begin{tabular}{l} 
Total \\
\hline
\end{tabular} & $\mathbf{4 0}$ & $\mathbf{2 3}$ & $\mathbf{6 3}$ & $\mathbf{1 0 0}$ \\
\hline
\end{tabular}

Table 2. Main constraints facing the emerging farmers; $n=63$

\begin{tabular}{lcc}
\hline Constraint & Frequency & Percentage \\
\hline Lack of funding & 46 & 73 \\
Limited access to water & 38 & 60 \\
Cost of electricity & 35 & 56 \\
Lack of knowledge about commercial & 31 & 49 \\
farming & & \\
Poor irrigation infrastructure & 28 & 44 \\
Fencing & 24 & 38 \\
Farming inputs & 23 & 37 \\
Farming machinery \& implements & 23 & 37 \\
Lack of markets for farmers' produce & 18 & 29 \\
Extension services & 11 & 25 \\
Transport services & 10 & 19 \\
\hline
\end{tabular}

with reliable access to water were able to utilise the water for agricultural production. Often, there were other challenges acting as a barrier to full farm production. The full range of major challenges as identified and articulated by the farmers is presented in Table 2.

Table 2 shows that at least $73 \%$ of the emerging farmers cited lack of funding as the biggest challenge facing them; limited access to water was considered the second biggest challenge at $60 \%$; costs of electricity came a close third at $56 \%$; and lack of commercial farming knowledge came fourth at $49 \%$. These findings suggest that policy makers and practitioners should pay more attention to lack of funding, costs of electricity, access to water, and capacity development for the emerging farmers.

We also noted that in Bela-Bela, most of the farms in our sample mainly relied on groundwater from boreholes, and these are associated with a range of limitations unique to them. Firstly, during the dry season, the borehole water levels recede such that more energy is required for pumping the water out and thus reducing the quantities available. To illustrate, one of the respondents had this to say: 'the water level in the ground is very low, sometimes the water is completely unavailable during dry seasons. It usually takes too long to fill the balance dam, and sometimes water completely stops coming out.'

Agricultural extension officers in our study sites reported that, in most cases, the white predecessors for each farm used to have more than one functioning borehole, which allowed the farmer to rotate the boreholes when abstracting the water for irrigation from time to time. This is not the case with most of the current black owners, mainly because quite a number of the boreholes previously sunk on the farms have now either run into disrepair or have dried up. At least $60 \%$ of the farms in our sample had only one borehole which was functional. The boreholes require costly maintenance or complete replacement of the equipment. Some of the famers also indicated that they use very small pressure pumps to convey groundwater to the fields, and this means that they are only able to supply limited amounts of water for irrigation at a time.

\section{Access to water versus farm performance}

It is well documented that water availability affects food production. In order to gain a better understanding of this issue, each farm production process was assessed in relation to the status of its access to water. The overall farm assessment from the study sites is as presented in Table 3.

As reflected in Table 3, at least $22 \%$ of the sampled farms were fully commercially functional, with reliable access to water assured while $37 \%$ were not commercially functional at all and had serious challenges in accessing water. About $16 \%$ of the farms were commercially functional even though they had some challenges in accessing water while $14 \%$ of the farms were not commercially functional even though they had reliable access to water. This suggests that water is not the only limiting factor

Table 3. Access to water and farm production in Bela-Bela and Groblersdal, $n=63$

\begin{tabular}{|c|c|c|c|c|}
\hline Assessment dimension & Bela-Bela & Groblersdal & Total & Percentage \\
\hline Farm is fully commercially functional \& has reliable access to water & 8 & 6 & 14 & 22 \\
\hline $\begin{array}{l}\text { Farm is not fully commercially functional but has reliable access to } \\
\text { water }\end{array}$ & 4 & 5 & 9 & 14 \\
\hline Farm is commercially functional but has challenges in accessing water & 6 & 4 & 10 & 16 \\
\hline $\begin{array}{l}\text { Farm is not fully commercially functional \& has some minor challenges } \\
\text { in accessing water }\end{array}$ & 5 & 2 & 7 & 11 \\
\hline $\begin{array}{l}\text { Farm is not commercially functional at all and has serious challenges in } \\
\text { accessing water }\end{array}$ & 17 & 6 & 23 & 37 \\
\hline Total & 40 & 23 & 63 & 100 \\
\hline
\end{tabular}


to agricultural production among the emerging farmers. We also noted that in cases where the farms face some challenges around access to water but are still commercially functional, they had found alternative sources of livelihood such as dryland cropping, livestock and poultry production. This situation was particularly prominent in Groblersdal.

Some of the areas where the emerging farmers are situated in Groblersdal usually receive good rainfall, which enables them to grow crops and produce quite well without relying on irrigation. This was particularly evident in areas such as Stoffberg where they receive between 700 and $800 \mathrm{~mm}$ of rainfall per annum, but due to variability in precipitation patterns, it is not always guaranteed that the rainfall received will be adequate each year. Therefore, access to water for irrigation would still be needed for the emerging farmers to mitigate drought conditions and midseason dry spells.

We also noted that, unlike the situation in Bela-Bela, there is a wider variety of water sources for the land reform farms in Groblersdal. These include several rivers and streams which pass through some of the farms, and dams such as Loskop which supply many farms with water using canals. However, there are regulatory restrictions associated with these water sources such that access to water from them is not necessarily guaranteed for the emerging farmers.

\section{The water licensing dilemma}

The National Water Act 36 of 1998 forms the basis for current agricultural water policy in South Africa. The Act separates ownership of land from ownership of water (riparian rights) and vests the latter in the state. Under this Act, agricultural producers (including smallholder farmers in some cases) are required to register as water users and formally obtain licenses to get access to water through specific volumetric allocations. Once the farmers are registered, they will also be expected to join a Water User Association, which regulates and manages the allocation and abstraction of water from all surface water sources in their respective areas of jurisdiction.

While this system enables the state to set aside water for basic needs and ecological purposes as necessary, water permits from the previous water governance regime are still recognized, such that the emerging farmers do not necessarily get automatic access to water, particularly in cases where the rivers are already fully allocated. This situation essentially serves the interests of large-scale white commercial farmers, whose families obtained water permits a long time ago during apartheid, rather than those of emerging black farmers. The status of water licenses and permits in Bela-Bela and Groblersdal presented in Fig. 2 is revealing in this regard.

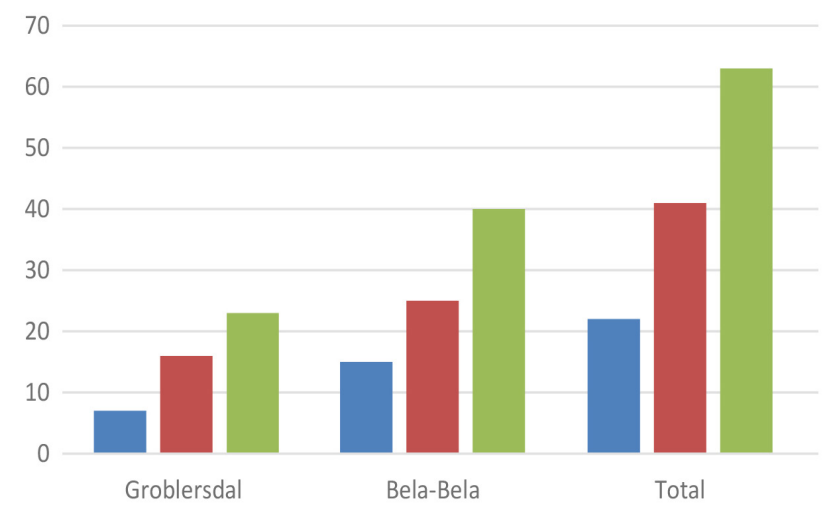

Figure 2. Status of water license ownership among the farmers
It is also important to note that farmers from the two study sites derive water from different sources, with the majority of farmers in Bela-Bela abstracting most of their water from boreholes, whereas those in Groblersdal mainly abstract their water from surface water bodies such as dams and rivers. This produces different patterns in terms of their perceptions about the need to register for water use rights. As a result, most of the farmers in Bela-Bela who use boreholes to access water did not have water permits or licenses even though the law requires them to be registered if they exceed a water abstraction rate of $10 \mathrm{~m}^{3}$ per day (see RSA, 1998). However, knowledge about these requirements is not widespread among the farmers and enforcement is also not easy at all. Thus, most of the farmers using groundwater are not registered, even in cases where they would be abstracting more than $10 \mathrm{~m}^{3}$ per day.

We established that about $65 \%$ of the farmers in our sample did not have water licenses. They expressed a number of factors limiting them from getting the licences. One of the main reasons that they cited is that the government offices that are supposed to assist them in obtaining water licenses are not sufficiently responsive. One of the farmers stated that 'we are always ordered to wait for the permit processing, although not told how long it will take to process our request, and also not told what may be causing the delay'.

Most of the farmers in our sample (55\%) indicated that they are not aware that they are supposed to register and obtain water licences for groundwater. In addition, some of the farmers who are aware of this requirement indicated that they do not know the process to follow in order to obtain the water licences. Some of those who have applied for the licenses also indicated that it takes a very long time to finally obtain a license. In addition, some of the white farmers who previously owned the land transferred their water use permits to other white farmers who are still operating in the area once it became clear that they were going to lose their land through the redistribution programme. This makes it difficult for the new occupants of the farms to acquire additional water licences. As a result, we have a situation where white commercial farmers continue having better access to agricultural water than the black emerging farmers. It also gives the white commercial farmers more decision-making privileges and power in terms of sitting on water boards and catchment management agencies as they have a greater stake than the emerging farmers.

\section{Support infrastructure for accessing and utilising water}

Access to water, particularly for irrigation purposes, does not only depend on the availability of water sources or use rights. It also depends on the existence of certain infrastructure that enables water to be conveyed from the source to the site where it is needed. For instance, electricity to pump groundwater or operate irrigation equipment was cited as one of the major constraints to efficient utilization of the water that is already available on the farms we studied. Most of the farmers interviewed in the study sites indicated that the electricity tariffs charged are beyond their reach and this worsened their ability to access water. In some cases, electricity transformers on the farms have also been stolen or vandalised and the emerging farmers are expected to pay for the replacement fee.

There are cases where the electricity supply on some of the farms has been cut off due to outstanding bills or failure to pay for transformer replacement. In some cases, the farmers have opted to use diesel generators to pump the water but this is quite expensive and not sustainable in the long term. Against this backdrop, access to water for the emerging farmers is generally limited and, hence, providing alternative and affordable power 
sources such as off-grid solar energy becomes necessary. In some cases, there are no water meters to accurately measure water abstraction by the emerging farms. The water bills are produced based on rough estimates and this often results in the farmers receiving huge bills that are disproportionate to actual water use. This consequently places a heavy financial burden on some of the emerging farmers.

\section{Water storage facilities and irrigation equipment}

On most of the farms in our sample, water flow capacity is not sufficient to immediately meet the consumption requirements of the farm operations and thus extra water storage facilities such as tanks are required. Very few of the farmers we visited had sufficient water storage on the farms. Although in many cases water storage facilities are inherited with the land, the lack of maintenance under the new black owners was remarkable (Fig. 3).

Under the current conditions of water scarcity in the study sites, there is need for more than one water storage facility such as a dam or tank on each farm to augment water supplies for irrigation and domestic use. Having more water storage on the farm bridges the gap between the water demands for commercial use and the supply capacity from the main source. Having water tanks, for instance, enables augmentation through rainwater harvesting, but such facilities need to be developed and embedded into the main water supply system.

In addition, the majority of the farmers practicing crop production had irrigation equipment either funded by the government or inherited from the previous farm owner. However, there are also many emerging farmers who did not have any irrigation equipment at all, either because the government had not yet assisted them to get the equipment or the one they inherited with the land had become dysfunctional.

\section{DISCUSSION}

Our study findings demonstrate the inadequacy of implementing water and land reforms parallel to each other with no deliberate effort so far having been made to ensure that the two reform processes sufficiently complement each other. As a result, access to water for agricultural production is not necessarily guaranteed for some of the beneficiaries of land reform. In cases where there is no access to adequate water for the emerging farmers, production is immediately affected. Policy makers and practitioners have to revisit the reform programme model and ensure that the emerging farmers also get access to sufficient amounts of water for productive purposes (especially irrigation).
Inter-governmental departmental coordination for land and water reforms is crucial at the initial stages to ensure that evident gaps are addressed. It would also be beneficial to the emerging farmers if all key services such as access to water, land reform support and title deeds are provided prior to occupation of the land or very soon thereafter, in order to ensure that meaningful agricultural production is not delayed. This would certainly require strong coordination and collaboration among government departments such as the Department of Agriculture, Land Reform and Rural Development, the Department of Water and Sanitation, and Department of Public Works and Infrastructure.

This study revealed that most of the emerging farmers do not have enough capital for investing in the water and energy infrastructure they need for irrigation systems. Provision of subsidies on their electricity tariffs could partly alleviate their situation. It could also be useful to explore possibilities of providing alternative and cost-effective power sources such as off-grid solar and wind energy supply systems. Solar-based irrigation pumps are already being used in other parts of the world with a reasonable degree of success and there is no reason why this option should not be explored in South Africa. For instance, the PV-powered water pumping and desalination program in Saud Arabia is believed to be one of the most successful applications in remote areas (Alawaji, 2001). The aggressive promotion of solar pumps in groundwater-abundant eastern India significantly increased the potential to catalyse an ever-green revolution in places where access to water was previously not guaranteed for small-scale farmers (Kishore et al., 2014). In the same vein, enabling the emerging farmers in BelaBela and Groblersdal to augment their water supplies through rainwater harvesting approaches also emerges as a viable option. Our study also revealed that commercial farming knowledge is widely lacking among the farmers. Therefore, capacity building interventions that enable the emerging farmers to gain the knowledge they need to run the farms efficiently and productively are required.

\section{CONCLUSION}

We set out to generate empirical data that demonstrates the extent to which access to water may or may not be assured for emerging farmers once they obtain redistributed land, as well as the main challenges that limit use of the water available for economic production in Bela-Bela and Greater Sekhukhune. Findings from this study have enabled us to reach firm conclusions on this. For the majority of the farmers, access to water is not guaranteed and this negatively affects their

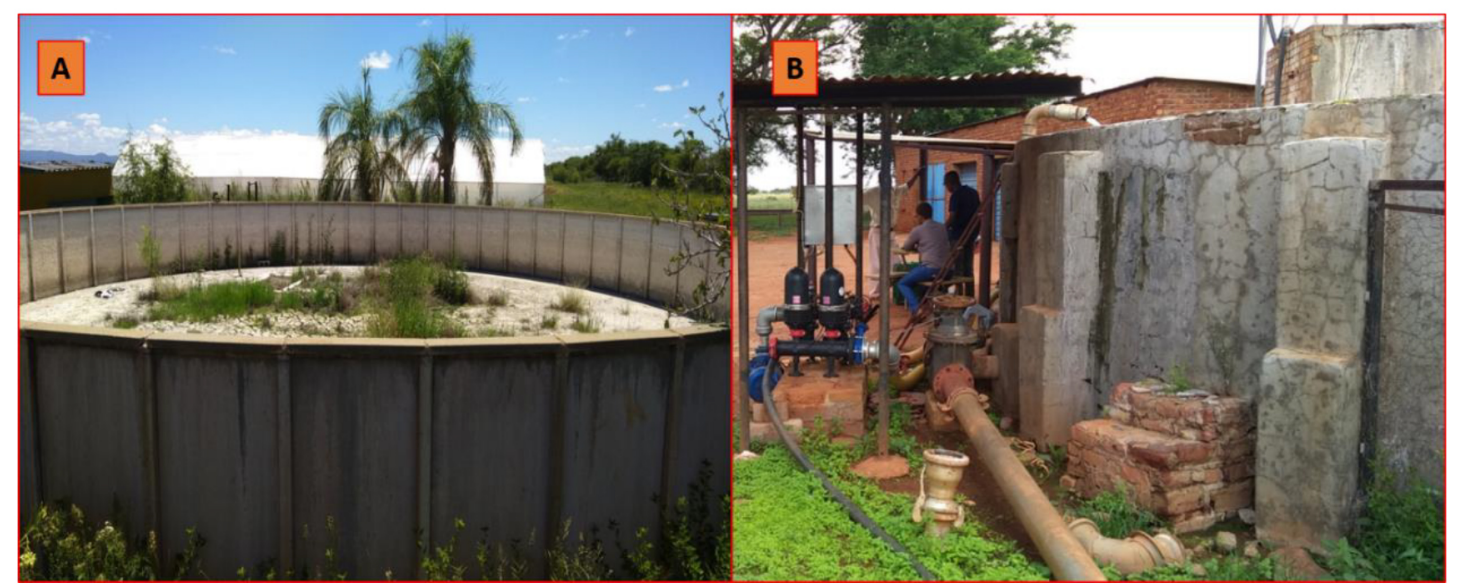

Figure 3. Typical water storage facilities in disrepair observed in Bela-Bela 
productivity and capacity for irrigated agriculture. The main factors affecting access to water and farmers' ability to use that water for commercial farming purposes, as articulated by the farmers themselves, include a cumbersome water licensing process, as well as other constraints beyond water, such as lack of knowledge for commercial farming; lack of finance for buying farm inputs, poor or non-existent irrigation equipment, and expensive electricity supply for pumping water to the fields.

Due to the diversity of the emerging farmers' capabilities and interests, water use patterns among them are not uniform. As a result, there are cases where those with reliable water supplies do not necessarily operate the farms at optimum production levels. While the equity motivations and spirit behind the land reforms are commendable, actual delivery of the reform objectives in terms of the drive towards irrigated agriculture remains in question and, therefore, targeted interventions are still needed that will ensure better access and use of water among the emerging farmers. This should include provision of more support for water supply augmentation infrastructure and alternative energy sources for pumping the water to the fields. It also seems that the integration of land reform and water access has not received sufficient attention. Therefore, careful integrated planning is required that brings together relevant government departments and other key actors to work together towards achieving the goal of enabling irrigated agricultural production by beneficiaries of land redistribution in South Africa.

\section{ACKNOWLEDGEMENTS}

Research for this paper was funded by the Volkswagen Foundation under the Programme: 'Knowledge for Tomorrow - Cooperative Research Projects in Sub-Saharan Africa on Livelihood Management, Reforms and Processes of Structural Change'.

\section{REFERENCES}

ALAWAJI SH (2001) Evaluation of solar energy research and its applications in Saudi Arabia - 20 Years of Experience. Renew. Sustainable Energ. Rev. 5 59-77. https://doi.org/10.1016/ S1364-0321(00)00006-X

ANDERSON A, EIMAN K and STEFANO F (2008) Synthesis: IWRM lessons for implementation. Water SA 34 (6) 665-669. https://doi. org/10.4314/wsa.v34i6.183667

ATUAHENE B (2011) South Africa's land reform crisis. Foreign Affairs 90 (4) $121-129$.

AYINKE OO (2011) Contract farming in developing emerging farmers in South Africa: Exploring the Gledhow Mansomini Sugarcane Scheme. Master's thesis, University of Stellenbosch.

BATE R AND TREN R (2002) The cost of free water: The global problem of water misallocation and the case of South Africa. The Free Market Foundation, Johannesburg.

BELA-BELA LOCAL MUNICIPALITY (2013) Draft Integrated Development Plan 2013/14. Bela-Bela Local Municipality, Bela-Bela.

CHIKAZUNGA D and PARADZA G (2012) Can smallholder farmers find a home in South Africa's food-system? Lessons from Limpopo Province. PLAAS, University of the Western Cape.

CARDNO AGRISYSTEMS LIMITED (2008) Understanding the economics of land reform in Limpopo and developing a best practice model for post-settlement land restitution. Cardno Agrisystems Limited Research Report, Polokwane.

COUSINS B (2005) Agrarian Reform and the 'Two Economies': Transforming South Africa's Countryside. In Hall R and Ntsebeza L (eds.) The Land Question in South Africa: The Challenge of Transformation and Redistribution. Programme for Land and Agrarian Studies, University of the Western Cape.

DRIMIE S, GERMISHUYSE T, RADEMEYER L and SCHWABE C (2009) Agricultural production in Greater Sekhukhune: The future for food security in a poverty node of South Africa. Agrekon 48 (3) 245-275. https://doi.org/10.1080/03031853.2009.9523826
FANADZO M, CHIDUZA C and MNKENI PNS (2010) Overview of smallholder irrigation schemes in South Africa: Relationship between farmer crop management practices and performance. Afr. J. Agric. Res. 5 (25) 3514-3523.

FAROLFI S and PERRET S (2002) Inter-sectoral competition for water allocation in rural South Africa: Analysing a case study through a standard environmental economics approach. Proceedings of the Conference of the Italian Society of Agricultural Economics (SIDEA), 12-14 September 2002, Florence.

GOLDIN J (2010) Water policy in South Africa: Trust and knowledge as obstacles to reform. Rev. Radical Polit. Econ. 42 (2) 195-121. https:// doi.org/10.1177/0486613410368496

GREATER SEKHUKHUNE CROSS BORDER DISTRICT MUNICIPALITY (2008) Integrated Development Plan: 2008/09. Greater Sekhukhune Cross Border District Municipality.

HALL R (2007) Transforming Rural South Africa? Taking Stock of Land Reform. In: Hall A and Ntsebeza L (eds.) The Land Question in South Africa: The Challenge of Transformation and Redistribution. HSRC Press, Cape Town.

HALL R (2009) Another countryside? Policy options for land and agrarian reform in South Africa. Institute for Poverty, Land and Agrarian Studies, University of the Western Cape, Cape Town.

HALL R (2010) The politics of land reform in post-apartheid South Africa, 1990 to 2004: A shifting terrain of power, actors and discourses. PhD thesis, University of Oxford.

HEETDERKS M (2015) Poverty in a transforming landscape: Research in Bela-Bela Local Municipality, Limpopo Province, South Africa. Master's thesis, Utrecht University.

KEMERINK JS, AHLERS R and VAN DER ZAAG P (2011) Contested water rights in post-apartheid South Africa: The struggle for water at catchment level. Water SA 37 585-594. https://doi.org/10.4314/wsa. v37i4.16

KEPE T (2009) Claassens, A. and B. Cousins (eds.) 2009. Land, power \& custom: Controversies generated by South Africa's Communal Land Rights Act.. DOI: http://doi.org/10.18352/ijc.197Review of land, power and custom: Controversies generated by South Africa's Communal Land Rights Act. Int. J. Commons 3 (1) 148-150. https:// doi.org/10.18352/ijc.197

KEPE T and TESSARO D (2014) Trading-off: Rural food security and land rights in South Africa. Department of Geography, University of Toronto. https://doi.org/10.1016/j.landusepol.2013.08.013

KISHORE A, SHAH T and TEWARI NP (2014) Solar irrigation pumps farmers' experience and state policy in Rajasthan. Economic and Political Weekly EPW March 8, 2014, Vol. XLIX No. 10. 55-62.

KLEINBOOI K (2010) Review of land reform in Southern Africa. PLAAS, University of the Western Cape, Cape Town.

LAHIFF E, MALULEKE T, MANENZHE T and WEGERIF W (2008) Land redistribution and poverty reduction in South Africa: The livelihood impacts of smallholder agriculture under land reform. PLAAS Research Report 36. University of the Western Cape, Cape Town.

LIEBRAND J, ZWARTEVEEN MZ, WESTER P and VAN-KOPPEN B (2012) The deep waters of land reform: land, water and conservation area claims in Limpopo Province, Olifants Basin, South Africa. Water Int. 37 (7) 773-787. https://doi.org/10.1080/02508060.2012.740613

LIMPOPO PROVINCIAL GOVERNMENT (2016) Provincial Review, 2016: The Real Economy Bulletin. Limpopo Provincial Government, Polokwane.

MAGOMBEYI MS, TAIGBENU AE and BARRON J (2013) Rural Poverty and Food Insecurity Mapping at District Level for Improved Agricultural Water management in the Limpopo River Basin. CPWF, Colombo.

MÉNDEZ-BARRIENTOS LE, KEMERINK JS, WESTER P and FRANÇOIS MOLLE F (2018) Commercial farmers' strategies to control water resources in South Africa: An empirical view of reform. Int. J. Water Resour. Dev. 34 (2) 245-258. https://doi.org/10. 1080/07900627.2016.1253544

MERREY DJ (2008) Is normative integrated water resources management implementable? Charting a practical course with lessons from Southern Africa. Phys. Chem. Earth 33 899-905. https://doi.org/10.1016/j.pce.2008.06.026

MERREY DJ, LÉVITE H and VAN KOPPEN B (2009) Are good intentions leading to good outcomes? Continuities in social, economic and 
hydro-political trajectories in the Olifants River Basin, South Africa. In: Molle and Wester (eds) River Basin Trajectories: Societies, Environments and Development. CABI International, Wallingford.

MOLOI MJ (2010) A comparison of socioeconomic characteristics that determine the farm income of emerging livestock and horticultural farmers in South Africa. PhD thesis, University of Limpopo.

MOVIK S (2009) The dynamics and discourses of water allocation reform in South Africa. STEPS Working Paper No. 21. STEPS Centre, Brighton.

MOVIK S (2014) A fair share? Perceptions of justice in South Africa's water allocation reform policy. Geoforum 54 (July) 187-195. https:// doi.org/10.1016/j.geoforum.2013.03.003

MSIBI ML and DLAMINI PZ (2011) Water allocation reform in South Africa: History, processes and prospects for future implementation. WRC Report No. 1855/1/11. Water Research Commission, Pretoria.

NATIONAL PLANNING COMMISSION (2012) Republic of South Africa National Development Plan, 2030. National Planning Commission, Pretoria.

NTSEBEZA L (2007) Land redistribution in South Africa: the property clause revisited. In: Ntsebeza L and Hall R (eds.) The Land Question in South Africa: The Challenge of Transformation and Redistribution. HSRC Press, Cape Town.

NOWATA J, BELETE A and NORRIS D (2014) Farmers perspectives towards the rehabilitation of the irrigation schemes in Sekhukhune District of the Limpopo Province, South Africa. J. Hum. Ecol. 48 (3) 383-391. https://doi.org/10.1080/09709274.2014.11906808

PERRET S (2002) Water policies and smallholding irrigation schemes in South Africa: A history and new institutional challenges. Working paper 2002-19. Department of Agricultural Economics, University of Pretoria.

RSA (Republic of South Africa) (1998) National Water Act (Act No. 36 of 1998). Government Gazette Vol. 398, 26 August 1998, Cape Town.

RSA (Republic of South Africa) (2012) Local Government Handbook: A Complete Guide to the Municipalities in South Africa. Government of South Africa, Pretoria

SCHREINER B, TAPELA B and VAN KOPPEN B (2010) Water for agrarian reform and rural poverty eradication: Where is the leak? In: Proceedings of the Conference on Overcoming Inequality and Structural Poverty in South Africa: Towards Inclusive Growth and
Development, 20-22 September 2010, Johannesburg. 1-23.

SCHREINER B and HASSAN R (2011) Transforming Water Management in South Africa: Designing and Implementing a New Policy Framework. Springer, Dordrecht and New York. https://doi. org/10.1007/978-90-481-9367-7

SCHULZE RE (1997) Climate. In: Cowling RM, Richardson DM and Pierce SM (eds.) Vegetation of Southern Africa. Cambridge University Press, New York. 21-42.

STATISTICS SOUTH AFRICA (1998) National Agricultural Survey. Stats SA, Pretoria.

STATISTICS SOUTH AFRICA (2002) National Agricultural Survey. Stats SA, Pretoria.

STATISTICS SOUTH AFRICA (2011) National Agricultural Survey. Stats SA, Pretoria.

STATISTICS SOUTH AFRICA (2012) National Agricultural Survey. Stats SA, Pretoria.

SWATUK LA (2010) The state and water resources development through the lens of history: A South African Case Study. Water Alt. 3 (3) 521-536.

THIAM DR, MUCHAPONDWA E, KIRSTEN J and BOURBLANC M (2015) Implications of water policy reforms for agricultural productivity in South Africa: Scenario analysis based on the Olifants River Basin. Water Resour. Econ. 9 60-79. https://doi.org/10.1016/j. wre.2014.11.001

UMHLABA (2010) A review of experiences of establishing emerging farmers in South Africa: Case lessons and implications for farmer support within land reform programmes. FAO, Rome.

URBAN-ECONOMICS (2007) Waterberg District Municipality: Local Economic Development Strategy - Final Draft. Urban-Econ., Pretoria

VAN KOPPEN B (2008) Redressing Inequalities of the Past from a Historical Perspective: The Case of the Olifants Basin, South Africa. Water SA 34 432-438. https://doi.org/10.4314/wsa.v34i4.183653

WOODHOUSE P (2012) Reforming land and water rights in South Africa. Dev. Change 43 847-868. https://doi. org/10.1111/j.1467-7660.2012.01784.x

WWF (World Wildlife Fund For Nature) (2014) Reconnecting South Africa's Food Systems to its Ecosystems. WWF-SA, Cape Town. 